\title{
Zanieczyszczenie wybranych próbek stałych węglowodorami aromatycznymi przy trasach wylotowych z miasta Olecko
}

Postępująca degradacja środowiska naturalnego zagraża istnieniu wielu organizmom. Większość organizmów jest przystosowana do przeżycia w specyficznych środowiskach i wymiera, gdy zostanie przekroczona bariera zdolności adaptacyjnych do poziomu zanieczyszczeń. Termin zanieczyszczenie środowiska" jest definiowany ogólnie, jako degradacja ekosystemu. Występuje, gdy obce substancje chemiczne i fizyczne, bądź biologiczne zmiany, oddziałują na życie człowieka, zwierząt i roślin niekorzystnie aż do wyraźnego szkodliwego wpływu. Monitorowanie skażenia środowiska stało się wymogiem i obecnie jest traktowane jako element kontroli i przewidywania zagrożeń. Trudno jest określić, które z bioindykatorów skażenia są najbardziej efektywne. Każdy element ekosystemu może być informatorem degradacji środowiska i wynikających zagrożeń dla zdrowia zwierząt i człowieka. Wprowadzane do celów monitoringu coraz to nowe bioindykatory pozwalają na bardziej precyzyjne określenie toksyczności i mechanizmu działania ksenobiotyków na organizmy wyższe. Równoczesne określanie toksyczności przemysłowych związków chemicznych, metali ciężkich, pestycydów i leków jest koniecznym wymogiem związanym z ich rozległym stosowaniem lub używaniem w przemyśle spożywczym czy farmaceutycznym.

Różnorodność form działalności człowieka powoduje wzrost ilości zanieczyszczeń wprowadzanych do środowiska. Wzrost stężeń poszczególnych składników, a zwłaszcza przekroczenie wartości granicznych, może powodować istotne skutki dla równowagi ekosystemu. Odnosi się to zwłaszcza do współistnienia różnych organizmów, zarówno roślinnych, jak i zwierzęcych. Najbardziej widocznym wpływem jest oddziaływanie substancji szkodliwych na organizm ludzki. W efekcie wzrastają wymogi granicy oznaczalności wszystkich substancji toksycznych i kancerogennych. Konieczność systematycznego kontrolowania jakości różnych elementów środowiska (wody, gleby, powietrza i żywności) stawia 
przed analitykami coraz wyższe wymagania i wyzwania, zarówno ze względu na opracowywanie nowych rozwiązań metodycznych, jak i aparaturowych.

Do typowych substancji toksycznych i kancerogennych zaliczane są wielopierścieniowe węglowodory aromatyczne (WWA). Występowały one w środowisku zawsze, jednak rozwój cywilizacji i technologii spowodował wzrost ich zawartości, co spowodowało realne zagrożenie zdrowia i życia organizmów żywych. WWA są zbudowane $z$ trzech lub większej liczby pierścieni aromatycznych ułożonych w różny sposób względem siebie. Do WWA można zaliczyć ponad 100 pojedynczych substancji zaliczanych do 5 grup chemicznych, pochodnych antracenu, fenantrenu, chryzenu, pirenu, cholantrenu, reprezentowanych odpowiednio przez: 1,2,5,6-dibenzoantracen, 3,4-benzoantracen, 5-metylochryzen, 3,4-benzopiren i 3-metylocholantren [1-3]. Poza działaniem mutagennym i kancerogennym WWA ważnym aspektem jest także ich działanie teratogenne [4]. Toksyczne efekty wywołane przez WWA mogą ulegać intensyfikacji poprzez zjawisko fotoindukcji.

Badania na organizmach wodnych wskazują, że WWA posiadają większy potencjał toksyczny w warunkach poddania eksponowanego na WWA organizmu, działaniu symulowanego promieniowania słonecznego, a wzrost toksyczności może być nawet 100-krotny. Wzbudzone cząsteczki WWA mogą przekazywać zgromadzoną energię na cząsteczkowy tlen i indukować procesy prowadzące do powstawania reaktywnych form tlenu zdolnych do wchodzenia w reakcje $\mathrm{z}$ makrocząsteczkami komórkowymi i wywoływania poważnych uszkodzeń o charakterze oksydacyjnym. Fototoksyczność WWA może mieć również wpływ na tworzenie się kowalentnych adduktów z DNA i/lub innych uszkodzeń nici DNA [5-7].

Problem zanieczyszczenia gleb, przede wszystkim uprawnych, stanowi istotną kwestię w dobie zachorowań na choroby nowotworowe. Na uwagę zasługuje fakt, że w wielu miejscach zaledwie kilka metrów od jezdni uprawiane są: owoce, warzywa, zboża, które następnie trafiają bezpośrednio lub pośrednio do organizmów ludzkich. Emisja WWA związana jest z komunikacją drogową [8-10]. W przypadku terenów wykorzystywanych rolniczo wysoki poziom zanieczyszczeń może również prowadzić do hamowania wzrostu roślin uprawnych i niekorzystnych zmian w plonowaniu $[8,9,12]$.

WWA, które dostały się do gleby mogą ulegać różnym przemianom fizykochemicznym (utlenianiu, sorpcji, rozkładowi chemicznemu) oraz mikrobiologicznym. Najistotniejsze znaczenie odgrywają procesy biodegradacji, które mogą prowadzić do pełnej mineralizacji tych substancji. Przemiany powodowane przez grzyby są niekorzystne, gdyż w ich wyniku mogą powstawać metabolity o bardzo silnych właściwościach rakotwórczych. Szybkość rozkładu WWA w glebach nie jest bezpośrednio uzależniona od ogólnej liczebności mikroorganizmów glebowych, ale od obecności specyficznych populacji mikrobiologicznych zdolnych do ich rozkładu $[13,14]$. 
Monitoring zanieczyszczeń środowiska, w którym żyjemy jest zawsze sprawą aktualną. Pomimo, że tereny północno-wschodniej Polski zaliczane są do tzw. zielonych płuc, nie oznacza to jednak, że nie ma tam źródeł zanieczyszczeń. Co prawda nie ma tu wielkich zakładów przemysłowych, ale coraz liczniejszy transport samochodowy staje się głównym źródłem powoli widocznych już zanieczyszczeń. Niniejsza praca jest kontynuacją badań dotyczących oceny stopnia zanieczyszczenia środowiska i wytwarzanej żywności pod kątem różnych związków toksycznych i kancerogennych północno-wschodniej Polski. Dlatego celem tej pracy było zbadanie zawartości 16 WWA w próbkach gleby i (rosnącej często) kapusty białej przy czterech głównych trasach wylotowych z Olecka (Rys. 1).

\section{Metodyka badań}

Głównym celem pracy było oznaczenie stężenia 16 WWA: naftalenu (Na), acenaftylenu (Ace), acenaftenu (Acn), fluorenu (Flu), fenantrenu (Fen), antracenu (An), fluorantenu (Fl), pirenu (Pir), benzo(a)antracenu (B[a]A), chryzenu (Ch), benzo(b)fluorantenu (B[b]F), benzo(k)fluorantenu $(B[k] F)$, benzo(a)pirenu $(\mathrm{B}[\mathrm{a}] \mathrm{P})$, dibenzo(a,h)antracenu $(\mathrm{B}[\mathrm{a}, \mathrm{h}] \mathrm{A})$, benzo $(\mathrm{g}, \mathrm{h}, \mathrm{i})$ perylenu $(\mathrm{B}[\mathrm{g}, \mathrm{h}, \mathrm{i}] \mathrm{P})$, indeno[1,2,3-c,d]pirenu (I[c,d]P), w próbkach gleby oraz kapusty białej przeznaczonej do spożycia. Zakres badań obejmował oznaczenie jakościowe i ilościowe WWA w pobranych próbkach oraz ocena stopnia zanieczyszczenia środowiska przez transport samochodowy na obszarze zaliczanym do najczystszego regionu Polski.

Miejsce pobierania próbek zlokalizowano w pasie terenu przylegającym do jezdni w odległości $10 \mathrm{~m}$. Próbki pobrano w sierpniu 2006 roku na trasach wylotowych z Olecka w kierunku: Suwałk, Gołdapi, Ełku i Giżycka. Analizie poddano próbki z dwóch punktów symetrycznie rozmieszczonych względem jezdni. Po przeprowadzonej analizie laboratoryjnej uzyskane zawartości WWA uśredniono.

\section{Część eksperymentalna}

Analizę zawartości WWA z badanych próbek przeprowadzono w następujący sposób: $10 \mathrm{~g}$ wysuszonego materiału badawczego ekstrahowano w aparacie Soxhleta przez $8 \mathrm{~h}$ za pomocą $150 \mathrm{ml}$ heksanu. Objętość otrzymanego ekstraktu odparowano do $4 \mathrm{ml}$. Następnie otrzymany ekstrakt przepuszczono przez kolumienkę SPE. Zaadsorbowane WWA eluowano mieszaniną acetonitrylu z toluenem ( $3 \times 3 \mathrm{ml}$ ) w stosunku objętościowym 3:1. Otrzymany ekstrakt odparowano do sucha i rozpuszczono w $2 \mathrm{ml}$ acetonitrylu. Przygotowaną próbkę poddano analizie techniką wysokosprawnej chromatografii cieczowej (HPLC), przy długości fali $254 \mathrm{~nm}$, w temperaturze $20^{\circ} \mathrm{C}$ i przepływie $1 \mathrm{ml} / \mathrm{min}$. 


\section{Dyskusja wyników}

Uzyskane wyniki badań zawartości WWA przedstawiono w tabelach $1-4$. Próbki gleby pobrano w miejscach uprawy kapusty. Porównując zawartości WWA w próbkach gleby i kapusty stwierdzono, iż pomimo 10 metrów odległości od jezdni, głównego źródła zanieczyszczeń, w badanym materiale stwierdzono obecność WWA. W próbkach gleby największe sumaryczne stężenie WWA (750 $\mu \mathrm{g} / \mathrm{kg} \mathrm{s.} \mathrm{m.)} \mathrm{odnotowano} \mathrm{przy} \mathrm{trasie} \mathrm{wylotowej} \mathrm{w} \mathrm{kierunku} \mathrm{Suwałk} \mathrm{(Tabela} \mathrm{1),}$ natomiast w próbkach kapusty ( $313 \mu \mathrm{g} / \mathrm{kg}$ s. m.) przy trasie w kierunku Gołdapi (Tabela 2). Fakt ten prawdopodobnie związany jest $z$ większym natężeniem pojazdów, które udają się w kierunku przejścia granicznego. Pocieszające jest to, iż w żadnej próbce zarówno gleby, jak i kapusty nie stwierdzono WWA o charakterze kancerogennym. W próbkach kapusty (kierunek: Suwałki, Tabela 1) dominującymi węglowodorami były: naftalen, acenaftylen i fluoranten. Najnizszą sumaryczną zawartość WWA odnotowano w pobranych próbkach w kierunku Giżycka (Tabela 3), odpowiednio $484 \mu \mathrm{g} / \mathrm{kg} \mathrm{s.} \mathrm{m.} \mathrm{w} \mathrm{glebie} \mathrm{i} 205 \mu \mathrm{g} / \mathrm{kg} \mathrm{s.} \mathrm{m.} \mathrm{w} \mathrm{kapuście.}$ Trasa ta charakteryzuje się mniejszym udziałem samochodów ciężarowych w sumarycznym natężeniu ruchu. Uzyskane wyniki wskazują na wyraźny wpływ arterii komunikacyjnej na poziom WWA w glebie i kapuście. Porównywalne dane prezentują autorzy cytowanych prac [9-11,13].

Duża liczba węglowodorów aromatycznych stwierdzonych w próbkach kapusty, świadczy o zanieczyszczeniu powietrza przez te związki. Duża powierzchnia liści kapusty charakteryzuje się doskonałą sorpcją WWA z zanieczyszczonego powietrza. Stąd stwierdzona obecność kolejnych killku węglowodorów w badanych próbkach.

Warstwa próchnicza gleby charakteryzuje się wysoką sorpcją węglowodorów, dlatego kontrola poziomu zanieczyszczeń jest sprawą bardzo ważną. Rośliny uprawiane na zanieczyszczonych glebach sorbują również te związki, które stanowią zagrożenie dla życia i zdrowia człowieka.

Związkami dominującymi w większości analizowanych próbek były: naftalen, acenaftylen i acenaften - węglowodory nie odznaczające się właściwościami rakotwórczymi, o czym wcześniej donosili autorzy [9-13]. Istotnym faktem jest to, że w analizowanych próbkach nie stwierdzono obecności żadnego rakotwórczego węglowodoru.

Analiza otrzymanych wyników w odniesieniu do wyników podobnych badań innych autorów wskazuje na niewielkie zanieczyszczenie badanych gleb, a tym samym próbek kapusty. Ocenę stopnia zanieczyszczenia przebadanych próbek można oprzeć na wynikach badań innych autorów. Niewielkie zawartości WWA znajdowali Borneff i Kunte w glebach z rejonów na południe od Darmstadt, oddalonych od zakładów przemysłowych i skupisk ludności [11]. Stężenia benzo(a) pirenu stwierdzone $\mathrm{u}$ tych autorów nie przekraczały kilku $\mu \mathrm{g} / \mathrm{kg}$, benzo $(\mathrm{g}, \mathrm{h}, \mathrm{i}) \mathrm{pe}$ - 
rylenu wahały się w granicach $10-70 \mu \mathrm{g} / \mathrm{kg}$, a benzo(b)fluorantenu sięgały do 110 $\mu \mathrm{g} / \mathrm{kg}$. W badaniach wykonanych w Norwegii, na obszarach reprezentujących zawartość WWA na poziomie naturalnego tła, Aamot i inni wykrywali do 128 $\mu \mathrm{g} / \mathrm{kg}$ fluorantenu i do $58 \mu \mathrm{g} / \mathrm{kg}$ benzo(a)pirenu [12].

Dopuszczalna zawartość WWA wg polskiej normy w glebie grupy A wynosi $1 \mathrm{mg} / \mathrm{kg}$ suchej masy [14]. W badanych glebach nie stwierdzono sumarycznego przekroczenia tej wartości, ani dopuszczalnych wartości pojedynczych PAHs. Benzo(a)piren uznany za najbardziej rakotwórczy nie występował wcale, podczas gdy dopuszczalna jego zawartość dla gleb nie zanieczyszczonych wynosi 0,02 $\mathrm{mg} / \mathrm{kg}$ suchej masy.

Z otrzymanych danych wynika, że średnie zawartości poszczególnych WWA w badanych próbkach nie przekraczają dopuszczalnych norm i kształtują się na poziomie koncentracji uznawanej w literaturze za naturalną.

Całość badań wskazuje na dwa aspekty wykonanej pracy. Aspekt naukowy polega na wartościach poznawczych, które określają źródła zanieczyszczenia gleb w pobliżu arterii komunikacyjnych, a także oceniają dynamikę sorpcji w zanieczyszczeniu środowiska związkami organicznymi o charakterze nowotworowym. Praktyczna wartość pracy polega na możliwości zastosowania uzyskanych wyników do oceny zanieczyszczenia gleby oraz otrzymywanych z niej produktów przeznaczonych do bezpośredniej lub pośredniej konsumpcji. Prezentowane wyniki będą z pewnością wykorzystane przez innych autorów do interpretacji uzyskiwanych przez nich wyników. Jednocześnie wskazują na konieczność rozpatrywania dynamiki sorpcji, badanych składników przez poszczególne elementy środowiska, stosowanie korelacji i prognozowania. Pokazują także ważność zjawiska sorpcji przy ocenie zanieczyszczenia środowiska.

\section{Wnioski}

W pobliżu dróg publicznych miasta Olecko widoczny jest już wpływ ruchu pojazdów na poziom WWA w glebie i roślinach uprawnych. Warstwa próchnicza gleby wykazuje wysoką sorpcję badanych związków organicznych. Monitoring biologiczny stanowi ważną ocenę dynamiki pojawiania się i rozkładu w różnych elementach środowiska substancji szkodliwych. Wskazuje istotne drogi wchłaniania tych związków do ustroju, co pozwala na ukierunkowanie poczynań zapobiegawczych. Biorąc pod uwage zanieczyszczenia badanych gleb przez WWA w porównaniu do gleb pochodzących z obszarów o podobnym stopniu antropopresji należy stwierdzić, że nie odznaczają się one wysokim poziomem WWA. 


\section{Literatura}

[1] Agency for Toxic Substances and Disease Registry (ATSDR) Public Health Statement. Polycyclic Aromatic Hydrocarbons. Atlanta 1990.

[2] Agency for Toxic Substances and Disease Registry (ATSDR); GA: U.S. Department of Health and Human Services, Public Health Service: Toxicological Profile for Polycyclic Aromatic Hydrocarbons. Atlanta 1995.

[3] Angerer J., Mannschreck C., Gundel J.: Biological Monitoring and Biochemical Effect Monitoring of Exposure to Polycyclic Aromatic Hydrocarbons. Int. Arch. Occup. Environ. Health. 1997, 70, 365-377.

[4] Van Shooten F.J., Moonen E.J.C., Van der Wal L., Levels P. Kleinjans J.C.S.: Determination of Polycyclic Aromatic Hydrocarbons (PAH) and Their Matabolites in Blood, Feces and Urine of Rats Orally Exposed to PAH Contaminated Soil. Arch. Environ. Contam. Toxicol. 1997, 33, 317-322.

[5] Dong S., Hvang H.M., Harrison C., Holloway L., Shi X., YU H.: UVA Light-Induced DNA Cleavage by Selected Polycyclic Aromatic Hydrocarbons. Bull. Environ. Contam. Toxic. 2000, 64, 467-474.

[6] Hoard D.E., Ratliff R.L., Bingham I.M., Striste G.F.: Reaction Induced in Vitro Between Model DNA and Benzo[a]pyrene by Ultraviolet Radiation. Chem. Biol. Interact. 1981, 33, 179-194.

[7] Striste G.F., Martinez E., Martinez A.M., Brake R.I.: Photo-Induced Reactions of Benzo[a]pyrene with DNA in Vitro. Cancer. Res. 1980, 40, 245-252.

[8] Kochany J., MaguiRe R.J.: Abiotic transformations of polynuclear aromatic hydrocarbons and polynuclear aromatic nitrogen heterocycles in aquatic environments. Sci. Total Environ. 1994, $17,144-151$.

[9] Adamczewska M., Siepak J., Gramowska H.: Studies of Levels of Polycyclic Aromatic Hydrocarbons in Soil Subjected to Anthropopressure in the City of Poznań, Pol. J. Environ. Studies 2000, 9 (4) 305-312.

[10] Baran S., OleszczuK P.: Oznaczanie wielopierścieniowych weglowodorów aromatycznych w glebach i odpadach organicznych metoda HPLC-UV. Act. Agroph. 2001, 48, 7-16.

[11] BorneFF J., Kunte H.: Carcinogenic substances in water and soil - XXII: Further investigations for PAH in soil samples. Arch. Hyg. Bakt., 1963; 147: 401-412.

[12] Aamot R., Krane J., STeiness E.: Determination of trace amounts of polycyclic aromatic hydrocarbons in soil. Fres. Z. Anal. Chem. 1987, 328, 569-575.

[13] Smreczak B., Wielopierścieniowe weglowodory aromatyczne (WWA) w układach Gleba - roślina wyższa. Roczniki Gleboznawcze, tom XLVIII nr 3/4, Warszawa 1997, 37-47.

[14] Rozporządzenie Ministra Środowiska z dnia 9 września 2002 r. w sprawie standardów jakości gleby oraz standardów jakości ziemi (Dz. U. Nr 165, poz. 1359). 
Zanieczyszczenie wybranych próbek stałych węglowodorami aromatycznymi...

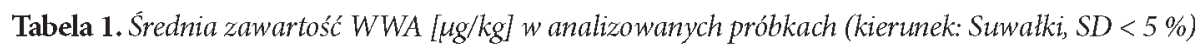

\begin{tabular}{|l|c|c|}
\hline \multicolumn{1}{|c|}{ Skrót WWA } & Gleba & Kapusta biała \\
\hline $\mathrm{Na}$ & 212 & 64 \\
\hline Ace & 231 & 38 \\
\hline Acn & 142 & 14 \\
\hline Flu & 54 & 29 \\
\hline Fen & 61 & 33 \\
\hline An & 34 & 11 \\
\hline Fl & 12 & 2 \\
\hline Pir & 3 & - \\
\hline B[a]A & - & 1 \\
\hline Ch & 1 & - \\
\hline B[b]F & - & - \\
\hline B[k]F & - & - \\
\hline B[a]P & - & - \\
\hline D [a,h)A & - & - \\
\hline B[g,h,i)P & - & - \\
\hline I[1,2,3-c,d]P & - & - \\
\hline$\sum$ WWA & -50 & 192 \\
\hline$\sum$ WWA kancer. & - & - \\
\hline
\end{tabular}

- nie stwierdzono

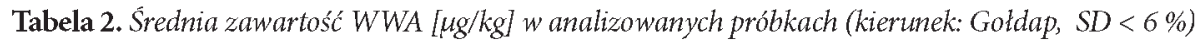

\begin{tabular}{|l|c|c|}
\hline \multicolumn{1}{|c|}{ Skrót WWA } & Gleba & Kapusta biała \\
\hline $\mathrm{Na}$ & 137 & 96 \\
\hline Ace & 182 & 112 \\
\hline Acn & 46 & 11 \\
\hline Flu & 93 & 53 \\
\hline Fen & 78 & 23 \\
\hline An & 13 & 2 \\
\hline Fl & - & 1 \\
\hline Pir & 24 & 13 \\
\hline B[a]A & - & 2 \\
\hline Ch & 2 & - \\
\hline B $[\mathrm{b}] \mathrm{F}$ & - & - \\
\hline B $[\mathrm{k}] \mathrm{F}$ & - & - \\
\hline $\mathrm{B}[\mathrm{a}] \mathrm{P}$ & - & - \\
\hline $\mathrm{D}[\mathrm{a}, \mathrm{h}) \mathrm{A}$ & - & - \\
\hline
\end{tabular}




\begin{tabular}{|l|c|c|}
\hline $\mathrm{B}[\mathrm{g}, \mathrm{h}, \mathrm{i}) \mathrm{P}$ & - & - \\
\hline $\mathrm{I}[1,2,3-\mathrm{c}, \mathrm{d}] \mathrm{P}$ & - & - \\
\hline$\Sigma$ WWA & 575 & 313 \\
\hline ¿ WWA kancer. & - & - \\
\hline
\end{tabular}

- nie stwierdzono

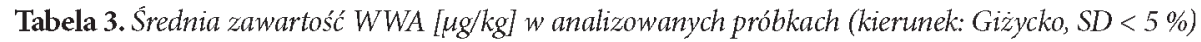

\begin{tabular}{|l|c|c|}
\hline \multicolumn{1}{|c|}{ Skrót WWA } & Gleba & Kapusta biała \\
\hline $\mathrm{Na}$ & 138 & 72 \\
\hline Ace & 121 & 54 \\
\hline Acn & 43 & 11 \\
\hline Flu & 56 & 23 \\
\hline Fen & 71 & 29 \\
\hline An & 32 & 12 \\
\hline Fl & 12 & 3 \\
\hline Pir & 7 & 1 \\
\hline $\mathrm{B}[\mathrm{a}] \mathrm{A}$ & 1 & - \\
\hline $\mathrm{Ch}$ & 3 & - \\
\hline $\mathrm{B}[\mathrm{b}] \mathrm{F}$ & - & - \\
\hline $\mathrm{B}[\mathrm{k}] \mathrm{F}$ & - & - \\
\hline $\mathrm{B}[\mathrm{a}] \mathrm{P}$ & - & - \\
\hline $\mathrm{D}[\mathrm{a}, \mathrm{h}) \mathrm{A}$ & - & - \\
\hline $\mathrm{B}[\mathrm{g}, \mathrm{h}, \mathrm{i}) \mathrm{P}$ & - & - \\
\hline $\mathrm{I}[1,2,3-\mathrm{c}, \mathrm{d}] \mathrm{P}$ & - & - \\
\hline$\sum$ WWA & 484 & 205 \\
\hline$\sum$ WWA kancer. & - & - \\
\hline
\end{tabular}

- nie stwierdzono

Tabela 4. Średnia zawartość WWA $[\mu g / k g]$ w analizowanych próbkach (kierunek: Elk, SD<7\%)

\begin{tabular}{|l|c|c|}
\hline \multicolumn{1}{|c|}{ Skrót WWA } & Gleba & Kapusta biała \\
\hline $\mathrm{Na}$ & 79 & 22 \\
\hline Ace & 182 & 117 \\
\hline Acn & 113 & 68 \\
\hline Flu & 65 & 24 \\
\hline Fen & 52 & 15 \\
\hline
\end{tabular}




\begin{tabular}{|l|c|c|}
\hline An & 36 & 8 \\
\hline Fl & 14 & 3 \\
\hline Pir & 4 & 1 \\
\hline B[a]A & 1 & - \\
\hline Ch & 1 & 1 \\
\hline B $[\mathrm{b}] \mathrm{F}$ & - & - \\
\hline $\mathrm{B}[\mathrm{k}] \mathrm{F}$ & - & - \\
\hline $\mathrm{B}[\mathrm{a}] \mathrm{P}$ & - & - \\
\hline $\mathrm{D}[\mathrm{a}, \mathrm{h}) \mathrm{A}$ & - & - \\
\hline $\mathrm{B}[\mathrm{g}, \mathrm{h}, \mathrm{i}) \mathrm{P}$ & - & - \\
\hline $\mathrm{I}[1,2,3-\mathrm{c}, \mathrm{d}] \mathrm{P}$ & - & - \\
\hline$\sum$ WWA & 547 & 259 \\
\hline$\sum$ WWA kancer. & - & - \\
\hline
\end{tabular}

- nie stwierdzono

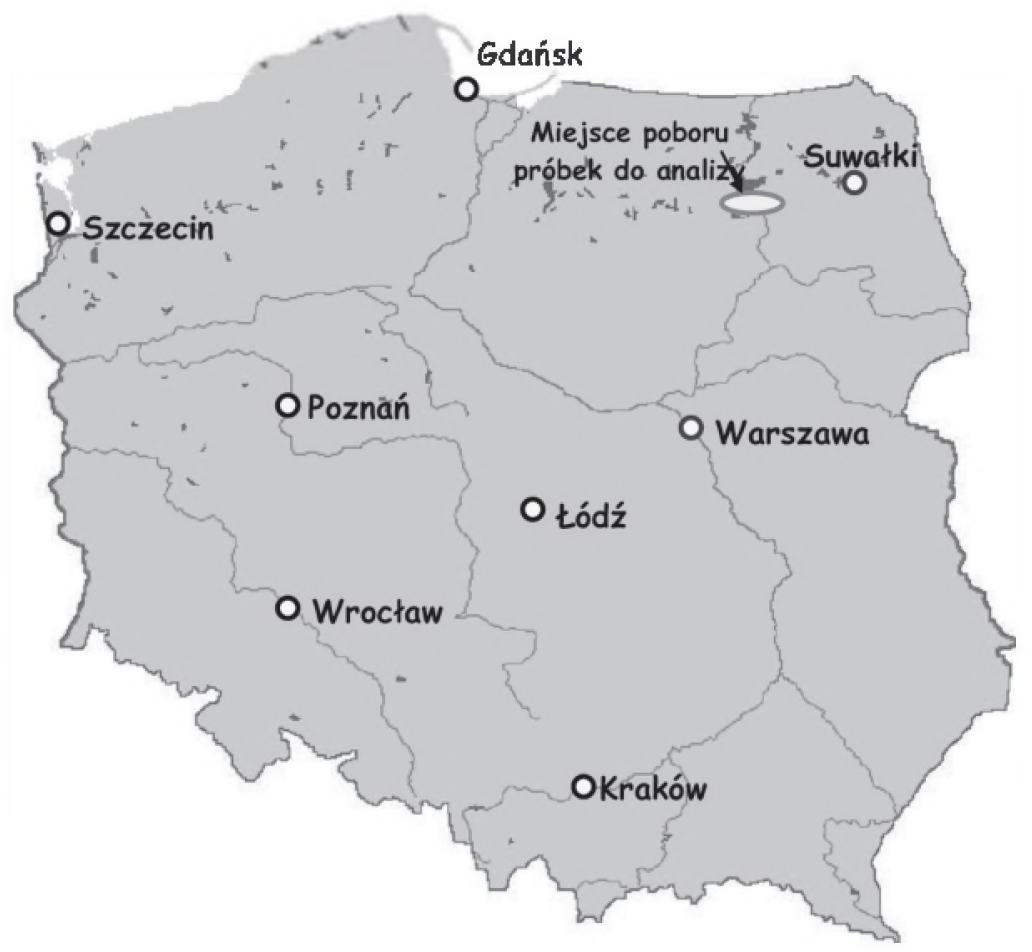

Rys. 1. Lokalizacja terenu poboru próbek do analizy 


\title{
PAHs contamination in chosen samples taken from the Olecko region
}

\begin{abstract}
SUMMARY
This paper presents the results of research conducted on some samples with soil and cabbage taken from the vicinity of Olecko town (Suwałki, Gołdapia, Ełk, Giżycko) and containing polycyclic aromatic hydrocarbons (PAHs) with 16 aromatic rings. The research is a continuation of a detailed monitoring of progressing pollution in the Olecko region. The samples were taken in August 2006 from the place situated $10 \mathrm{~m}$ from a road, this place was at the same time a cabbage plantation. The highest concentration of PAHs $(750 \mu \mathrm{g} / \mathrm{kg} \mathrm{s.} \mathrm{m}$.) was found in the sample taken close to the road from Olecko to Suwałki and in the sample with cabbage $(313 \mu \mathrm{g} / \mathrm{kg} \mathrm{s} . \mathrm{m}$.) taken near the road to Gołdapia. The lowest concentration of PAHs was stated in the samples taken in the vicinity of the road to Giżycko. The results don't overpass the limits permitted in Poland but, unfortunately, are close to the upper limit of natural concentration defined by scientific literature.
\end{abstract}

Keywords: environmental samples, sorption, concentration, PAHs, HPLC

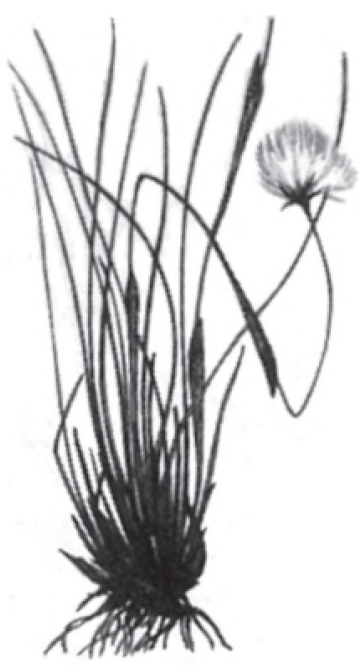

Welnianka pochwowata 